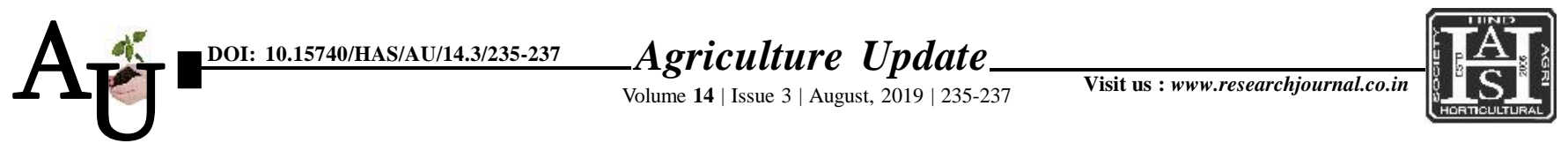

ISSN-0973-1520

\title{
Reserkch Articie: Impact of farm pond on beneficiary farmers in Amravati district
}

\section{A. S. Ade, V. V. Gohad, V. N. Suryvanshi and A. D. Sangle}

Article Chronicle: Received :

04.06.2019;

Revised :

12.07.2019;

Accepted :

23.07.2019

KEY Words:

Farm pond, Socio

economic, Impact
SUMMARY : The present study was conducted mainly with the specific objective to study. For the study Amravati district was selected and from this district four tahsils selected, from this tahsils five villages selected and from each village four beneficiaries were selected on the basis of maximum number of farm pond. For this study 80 respondents are selected. Ex-post facto research design was used for the research study. It was noticed that, 47.5 per cent respondents were educated upto middle school level, half 51.25 per cent of the respondents were having semi medium land holding, majority 75.00 per cent of the respondents had medium farming experience, majority 53.75 per cent of the respondents had low area under irrigation, majority 73.75 per cent of the respondents had medium family size, majority 65.00 per cent of the respondents had low social participation, most 66.25 per cent of the farmers medium extension contact, half of the respondents i.e. 47.5 per cent had medium economic motivation, half of the respondents i.e. 61.25 per cent were having medium risk preferences. The independent variables namely land holding, area under irrigation, family size, extension contact, risk preferences are positively and highly significant with impact of the farm pond beneficiaries at 0.01 level of probability. The variables namely education, farming experience, economic motivation are significantly correlated with impact of the farm pond beneficiaries at 0.05 level of probability. Whereas, social participation showed non-significant relationship with farm pond beneficiaries.

How to cite this article : Ade, A.S., Gohad, V.V., Suryvanshi, V.N. and Sangle, A.D. (2019). Impact of farm pond on beneficiary farmers in Amravati district. Agric. Update, 14(3): 235-237; DOI : 10.15740/HAS/AU/14.3/235237. Copyright@ 2019: Hind Agri-Horticultural Society.
Author for correspondence :

\section{V.V. Gohad}

Department of Extension Education, Shri Shivaji Agriculture College, Amravati (M.S.) India

See end of the article for authors' affiliations 